\title{
Organic Matter Amendments Improve Soil Health, Productivity and Profitability of Maize and Soybean
}

\author{
Imran* \\ Department of Agronomy, The University of Agriculture Peshawar, Pakistan
}

Submission: January 23, 2018; Published: February 13, 2018

"Corresponding author: Imran, Department of Agronomy, The University of Agriculture Peshawar, Pakistan, Email: imranagrarian@aup.edu.pk

Abstract

Field trials were conducted for consecutive two years (2016 \& 2017) at Agriculture Research Institute Mingora Swat, Pakistan to study the effect of various organic matter incorporation to soil on maize and soybean yield and soil health. Results reviled that phenological and Morphological traits responses of both crop were positive to organic matter incorporation. Pre and post-harvest soil analysis of the maize and soybean field showed that soil heath was significantly boosted with organic matter addition.

\section{Introduction}

Organic matter incorporation is an ancient age agriculture practices to enhance soil aeration, nutrients supply and water infiltration rate along with water holding capacity. In modern day agriculture practices, the organic matter amendments is proven beyond doubts in respect of their diverse role for soil health [1-3].

Initially it was used as supplement of chemical fertilizer to provide nutrients in abundance for crop growth and maintenance [4-9]. OM (manure and composted manure brings a lot of beneficial microorganisms that can act as PGPR. For degraded soil reclamation organic matter is mostly incorporated acts mainly as a source of nutrients, and improves some physical properties. On strongly degraded soils, mainly by acidity ( $\mathrm{pH}$ in $\mathrm{KCl}$ even of 3,2, in water probably about 4) the effect of single dose of farmyard manure last even 3 years or more and consists mainly on softening of negative effects of acidity (probably complexing of exchangeable $\mathrm{Al}$ ). It also depends on crop. It has been reported that, during 3 years the crop uptake (apparent) from farmyard manure was about of $25-40 \%$ of N, $20 \%$ P, 37 $55 \% \mathrm{~K}$ and $10 \%$ of $\mathrm{Mg}$ introduced with farmyard manure $[2,5,10-$ 12]. All manures are not the same the manure which gives the quick response is Vermi compost or earth worm castings. These are low in ammonia but have good nitrate concentration.

In addition they are high is soluble phosphate and the complete complement of needed nutrition including its excellent ability to supply Calcium. The use of a thermophilic turned leaf compost when amended with 10 to $20 \%$ castings gives season long and early growth stimulus. This is a best of both worlds all organic solution to many issues in feeding plants organically. It also saves on application since it is useful for early and later stage nutrition without unnecessary multiple lay by applications.
Vermi compost (VC) and plant residues (PR) are environmentally friendly materials. VC has many favorable physicochemical characteristics, making it suitable for mixture in substrates including high porosity, good aeration, drainage and water holding capacity (WHC). Vermi composting, in contrast to conventional compost, is the product of an accelerated biooxydation of organic matter by the use of high densities of earthworm populations without passing a thermophilic stage $[5,10,12,13]$. Different earthworm species are able to consume a wide range of organic residues such as sewage sludge, animal wastes ; crop residues; and industrial wastes.

The earthworm-processed organic wastes are finely divided peat-like materials with high porosity, aeration, drainage, and water-holding capacity sludge Compared to conventional compost which passes a thermophilic stage, vermicompost usually has a much finer structure and larger surface area providing strong absorbability and retention of nutrients. Based on all these characteristics, earthworm-processed organic waste would have a great commercial potential in the horticultural industry as container media for growing bedding and vegetable plants. There is strong scientific evidence that vermicompost can significantly influence the growth and productivity of plants. All these characteristics of soil known as soil health [14-29].

\section{Material and Methods}

Field experiment was conducted at Agriculture Research Institute Mingora Swat to evaluate the impact of organic matter on maize and soybean growth and yield. The design for study was used randomized complete block design with three replication of each crop. All recommended agronomic practices was followed till harvest of the crop [30-39]. 
Results and Conclusion

Phenological and Morphological traits responses of both crops were positive to organic matter incorporation. Pre and post-harvest soil analysis of the maize and soybean field showed that soil heath was significantly boosted with organic matter addition (Figure $1 \& 2$ ) [40].

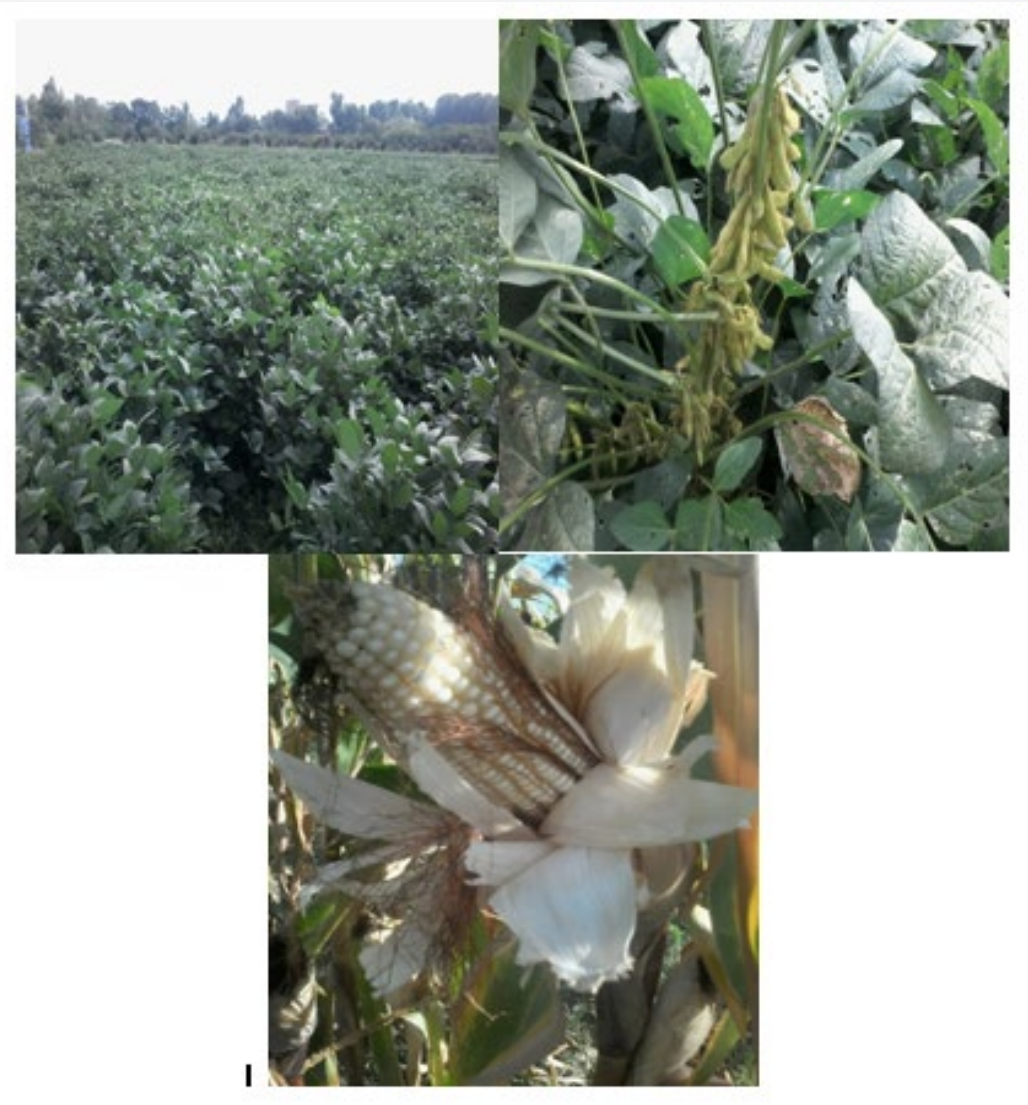

Figure 1

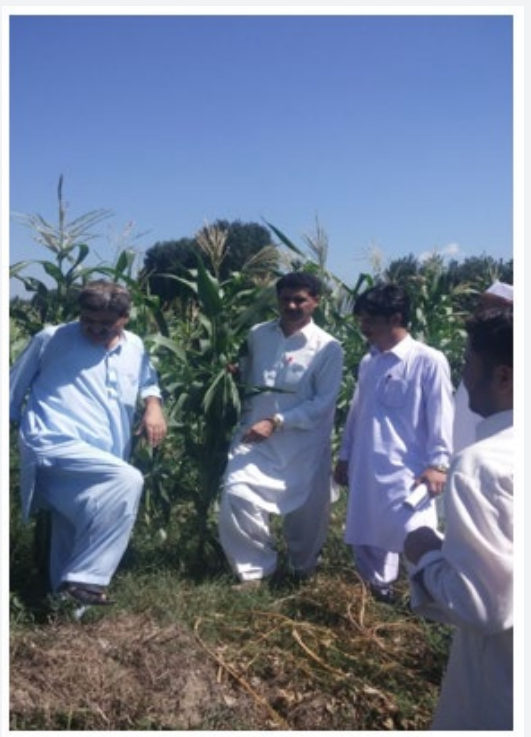

Figure 2 


\section{References}

1. Imran, AA Khan, I Ullah, H Zada, F Ahmad (2015) Yield And Yield Attributes Of Rapeseed Cultivars as Influence by Sulfur Level Under Swat Valley Conditions. Pure Appl Biol 4(3): 296-301.

2. Shazma Anwar, Israeel, Babar Iqbal, Asad Ali Khan, Imran, et al. (2016) Nitrogen And Phosphorus Fertilization Of Improved Varieties For Enhancing Phenological Traits of Wheat. Pure Appl Biol 5(3): 511-519.

3. Imran, Nasar Jamal, Ashfaq Alam, Asad Ali Khan (2017) Grain Yield, Yield Attributes of Wheat and Soil Physio-Chemical Charicteristics Influenced By Biochar, Compost And Inorganic Fertilizer Application. Agri Res \& Tech 10(4): 1-6.

4. Imran, Shahida Naveed, Asad Ali Khan, Inayat Khattak (2015) Impact of Phosphorus Levels and Seed Rates on Growth and Yield of Late Sown Maize on High Elevation in Swat, Pakistan. Pakistan J Agric Res 28(4): 406-413.

5. Ulfat Samreen, Muhammad Ibrar, Lalbadshah, Shahida Naveed, Imran, et al. (2016) Ethnobotanical Study Of Subtropical Hills Of Darazinda, Takht-E-Suleman Range F.R D.I. Khan, Pakistan. Pure and Applied Biology 5(1): 149-164.

6. Imran, AA Khan, Inamullah, Luqman (2015) Weeding Stages and their Effect on Yield and Yield Components of Rice in Upper Swat, Pakistan. Pak. J Weed Sci Res 21(4): 555-563.

7. A Khan, MN Khan, I Uallah, S Shah, IR Arshad, et al. (2015) Effect of Potash Application on Growth, Yield and Yield Components of Spring Maize Hybrids. Pure Applied Biology 4(2): 195-203.

8. Shamsuddin Baqa, Amir Zaman Khan, Inamullah, Imran, Asad Ali Khan, et al. (2015) Influence of Farm Yard Manure and Phosphorus Application on Yield and Yield Components of Wheat. J Pure Applied Biology 4(4).

9. Baber Iqbal, MT Jan, Imran, Zar MAA, Khan S (2015) Growth And Phenology Of Maize As Affected By Integrated Management Of Compost And Fertilizers Nitrogen. J Pure \& Applied Biology 4(4).

10. Babar Iqbal, Bashir Ahmad, Inam Ullah, Imran, Asad Ali Khan, et al. (2016) Effect of Phosphorus, Sulphur and Different Irrigation Levels on Phenological Traits of Triticale. Pure and Applied Biology 5(2): 303310 .

11. Amir Zaman Khan, Imran, Asim Muhammad, Aiman Khalil, Hasina Gul, et al. (2016) Impact of Fertilizer Priming on Seed Germination Behavior and Vigor of Maize. Pure Appl Biol 5(4): 744-751.

12. Shahida Naveed, Muhammad Ibrar, Inayat Khattak, Imtiaz Khan, Imran, et al. (2016) Anthelmintic, Antilice, Insecticidal, Cytotoxic and Phytotoxic Potential of Ethanolic Extracts of Two Wild Medicinal Plants Iphiona Grantioides And Plucheaarguta. J Woulfenia (23) 11: 13-25.

13. Babar Iqbal, Mohammad Tariq Jan, Zar Muhammad, Asad Ali Khan, Shazma Anwar, et al. (2016) Phenological Traits of Maize Influenced by Integrated Management of Compost and Fertilizer Nitrogen. J Pure Appl Biol 5(1): 58-63.

14. Imran, Khan AA (2017) Canola Yield And Quality Enhanced With Sulphur Fertilization. Russian Agricultural Sciences 43(2): 113-119.

15. Imran, Abdul Bari, Roshan Ali, Naeem Ahmad, Zulfiqar Ahmad, et al. (2017) Traditional Rice Farming Accelerate Ch4 \&N2o Emissions Functioning as a Stronger Contributors Of Climate Change. Agri Res \& Tech 9(3): 1-4.

16. Imran (2017) Climate Change is a Real fact Confronting to Agricultural Productivity. Int J Environ Sci Nat Res 3(3).

17. Iqbal A, Amanullah, Ali A, Iqbal M, Ikramullah (2017) Integrated Use of Phosphorus and Organic Matter Improve Fodder Yield of Moth Bean (Vigna Aconitifolia (Jacq.) Under Irrigated and dryland conditions of Pakistan. Journal of Agri search 4(1): 10-15.
18. Imran, AA Khan, IU Khan, S Naveed (2016) Weeds Density And Late Sown Maize Productivity Influenced By Compost Application And Seed Rates Under Temperate Environment. Pakistan Journal of Weed Science Research 22(1): 169-181.

19. Imran, Zada H, Naveed S, Khattak I, Ahmad S (2016) Variable Rates Of Phosphorous Application Influenced Phenological Traits Of Green Gram (VignaradiataL.) J Agri Res 1(3).

20. Imran, Asad Ali Khan, Inamullah Inam, Fayaz Ahmad (2016) Yield and Yield Attributes of Mungbean (Vigna Radiata L.) Cultivars As Affected By Phosphorous Levels under Different Tillage Systems. Cogent Food \& Agriculture 2(1).

21. Imran, I Khattak, I Hussain, A Rehman, S Anwar (2015) Growth and Yield of Maize Hybrids as Effected by Different Sowing Dates In Swat Pakistan. J Pure \& Applied Biology 4(4).

22. Imran, I Hussain, I Khattak, A Rehman, F Ahmad (2015) Roots Nodulation, Yield and Yield Contributing Parameters of Mungbean Cultivars as Influenced by Different Phosphorous Level in SwatPakistan. J Pure Applied Biology 4(4): 557-567.

23. Babar Iqbal, Muhammad Tariq Jan, Inamullah, Imran, Asad Ali Khan, et al. (2015) Integrated Management of Compost Type and Fertilizer-N in Maize. J Pure \& Applied Biology 4(4).

24. Muhammad Islam, Shazma Anwar, Saqib Bashir, Wajid Ali Khattak, Imran, et al. (2015) Growth And Yield Components of Wheat Varieties as Affected by Dual Purpose Practices. J Pure \& Applied Biology.

25. Imran, Muhammad Uzair, Fazal Maula, Marco Vacirca, Salvatore Farfaglia et al. (2015) Introduction And Promotion Of Off-Season Vegetables Production Under Natural Environment In Hilly Area of Upper Swat-Pakistan. Journal of Biology, Agriculture and Healthcare 5(11): 42-48.

26. Imran, Asad Ali Khan (2015) Effect of Transplanting Dates on Yield and Yield Components of Various Rice Genotypes in Hilly Area Cold Climatic Region of Khyber Pakhtunlhwa-Pakistan. Journal of Biology, Agriculture and Healthcare 5(7): 1-9.

27. Imran, Asad Ali Khan, Irfanullah, Fayaz Ahmad (2014) Production Potential of Rapeseed (Brassica NapusL.) as Influenced by Different Nitrogen Levels and Decapitation Stress Under the Rainfed AgroClimatic Condition of Swat Pakistan. J Glob Innov Agric Soc Sci 2(3): 112-115.

28. Imran, Asad Ali Khan, Fayaz Ahmad (2015) Phenology of Various Rice Genotypes as Affected by Different Transplanting Dates Under Cold Climatic Region of Khyber Pakhtunkhwa-Pakistan. Journal of Environment and Earth Science 5(3): 119-122.

29. Imran (2015) Effect of Germination on Proximate Composition of Two Maize Cultivars. Journal of Biology, Agriculture and Healthcare 5(3): 123-128.

30. Asad Ali Khan, Imran, Fawad Ali Shah, Inamullah Laiq Zada, Muhammad Naeem, et al. (2015) Phenological Traits of Rice as Influenced by Seedling Age and Number of Seedling Per Hill Under Temperate Region. Journal of Biology, Agriculture and Healthcare 5(3): 145-149.

31. Imran, Asad Ali Khan, Kashif Akhtar, SajjadZaheer, Shah Faisal, et al. (2015) Rice Seedling Characteristics of Various Genotypes Influenced by Different Sowing Dates in Swat-Pakistan. Journal of Environment and Earth Science 5(1): 122-125.

32. Imran (2015) Influence of Nitrogen Levels and Decapitation Stress on Biological Potential of Rapeseed (Brassica Napus L) Under Water Difficit Condition of Swat-Pakistan. Journal of Natural Sciences Research 5(3): 138-143.

33. Imran, Asad Ali Khan, Fayaz Ahmad, Irfanullah (2015) Nitrogen Levels, Tillage Practices and Irrigation Timing Influenced Yeild, Yeild Components and Oil Contents of Canola. Civil and Environmental Research 7(3): 74-77. 
34. Imran, Asad Ali Khan (2015) Phenological Charateristics of Brassica Napus L. as Influenced by Biochar Application and Shoot Cutting Duration (Days). Civil and Environmental Research 7(3): 104-107.

35. Imran, Asad Ali Khan, Fayaz Ahmad, Irfanullah (2015) Influence Of Hydrated Calcium Sulphate (Caso4.2 $\mathrm{h}_{2} \mathrm{o}$ ) and Nitrogen Levels on Water Infiltration Rate and Maize Varieties Productivity in Rainfed Area of Swat, Pakistan. Chemistry and Materials Research 7(3): 15-20.

36. Imran, Asad Ali Khan (2015) Grain Yield and Phenology of Maize Cultivars Influenced by Various Phosphorus Sources. Food Science and Quality Management 37: 74-78.

37. Imran, Asad Ali Khan (2015) Biochar Application And Shoot Cutting Duration (Days) Influenced Growth, Yield and Yield Contributing Parameters of Brassica Napus L. Journal of Biology, Agriculture and Healthcare 5(5): 1-6.
38. Imran, A sad Ali Khan (2015) Influence of Compost Application and Seed Rates on Production Potential of Late Sown Maize on High Elevation in Swat -Pakistan. J Environ And E Science.

39. Imran, Fazal Maula, Muhammad Uzair, Hayat Zada (2015) Farmers Income Enhancement through Off-Season Vegetables Production under Natural Environment in Swat-Pakistan Journal of Environment and Earth Science 5(5): 58-64.

40. Imran, Asad Ali Khan, Hayat Zada, Fayaz Ahmad, Irfanullah (2015) Graine Yield And Yield Components of Wheat Cultivar"Siran 2010" As Affected By Phosphorous Levels Under Rainfed Condition. Journal of Natural Sciences Research 5(5): 139-143.

Your next submission with Juniper Publishers
will reach you the below assets
- Quality Editorial service
- Swift Peer Review
- Reprints availability
- E-prints Service
- Manuscript Podcast for convenient understanding
- Global attainment for your research
- Manuscript accessibility in different formats
( Pdf, E-pub, Full Text, Audio)
- Unceasing customer service
Track the below URL for one-step submission
https://juniperpublishers.com/online-submission.php

